
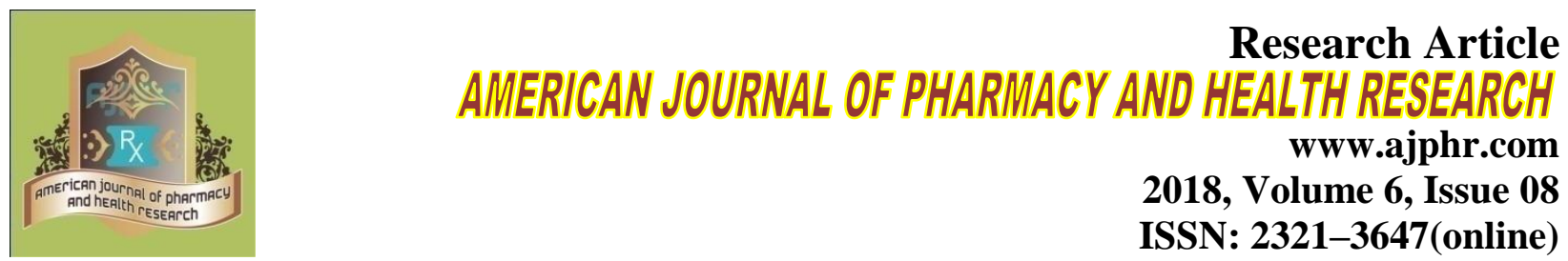

2018, Volume 6, Issue 08

ISSN: 2321-3647(online)

\title{
Investigation of Antidiarrhoeal and Antimotility Activities of Methanolic Extract of Musa Sapientum Flowers and Fruit Peels
}

Gourahari Panda, P. Narasimha Murthy, Iswori Prasad Padhy, Ghanshyam Panigrahi*

Department of Pharmacognosy, Royal College of Pharmacy and Health Sciences, Andhapasara

Road, Berhampur, Odisha, India, Pin -760002.

\begin{abstract}
The objective of the present study was investigation of antidiarrhoeal and antimotility activities of methanolic extract of musa sapientum (family- Musaceae) flowers and fruit peels. The phytochemical analysis of both extracts of Musa sapientum revealed the presence of alkaloids, carbohydrates, glycosides, saponins, proteins, coumarins, flavonoids, triterpenoids, tannins and phenolic compounds. The extracts were evaluated for castor oil- induced diarrhoea and intestinal motility test in rats. Both the methanolic extracts were significantly $(p<0.05)$ and dose dependently reduced frequency of stooling in castor oil-induced diarrhoea and anti-motility action in intestinal motility test. These findings suggest that the methanolic extract of the musa sapientum flowers and fruit peels may contain some biologically active ingredients that are useful for the treatment of diarrhoea.
\end{abstract}

Key words: Musa sapientum, Antidiarrhoeal, castor oil, antimotility, phytochemical 


\section{INTRODUCTION}

Diarrhoea is characterized by increased frequency of bowel movement, wet stool and abdominal pain. Diarrhea is an important health problem worldwide, especially in developing countries ${ }^{\mathbf{1}}$. It accounts more than 5-8 millions of death each year in infants and children under five years ${ }^{\mathbf{2}, 3}$. Despite massive technological advancement in modern medicine, many people in the developing countries still depend on the healing practices of use of medicinal plants for their daily health care needs. To fight this problem, the world health organization (WHO) has started a diarrhoea disease control program to study traditional medicine practices and other related aspects, together with the evaluation of health education and prevention approaches. Many public and private research institutions trying to control this disease, but the mortality rate of diarrhoea is still high in developing countries ${ }^{\mathbf{4 - 6}}$.

Musa sapientum (banana) belongs to the Musacaeae family. It is a large, perennial, monocotyledonous herb 2-9 $\mathrm{m}$ in height that arises from large, subterranean rhizomes, from which the leaves emerge. The entire above-ground portion of the plant is not a true woody trunk, as in other trees, but a "false trunk" or "false stem" that consists of leaves and their fused petiole bases, referred to as a pseudo-stem. The pseudo-stem supports a canopy consisting of 6-20 (or more) leaves. In the center of the leaves, a growing point forms from the top of the rhizome, grows up and emerges as an overhanging inflorescence with a succession of reddish brown bracts. The bracts unfold from the base to the tip and fall off. Within the lower 1-12 bracts arise 14-18 female flowers in double rows which develop into parthenocarpic fruits. The next few bracts contains bisexual flowers that are rich in nectar but do not develop any further. In the upper bracts only male flowers are formed ${ }^{\mathbf{7 1 0}}$. About 300 varieties of banana have spread throughout the tropical and subtropical countries and are widely used for its nutritional values all over the world. The fruits as well as the other parts of the plant are used to treat different diseases in human in traditional medicine. The fruit of Musa sapientum is traditionally used in diarrhoea (unripe), dysentery, intestinal lesions in ulcerative colitis, diabetes (unripe), uremia, nephritis, gout, hypertension, cardiac disease. Musa sapientum is also used in the treatment of excess menstruation. Banana leaves (ashes) are used in eczema, as cool dressings for blister and burns. Flowers are used in dysentery and menorrhagia. Stem juice of fruited plant is used for treating diarrhoea, dysentery, cholera, otalgia, haemoptysis and flower is used in dysentery, diabetes and menorrhagia. The root is used as anthelmintic, blood disorders, venereal diseases. The plant is also used in inflammation, pain and snakebite ${ }^{11-17}$. 
All these above mentioned traditional uses indicate that there must be some antidiarrhoeal property lying with the plant. In the present investigation the methanol extracts of Musa sapientum flowers and fruit peels were subjected for antidiarrhoeal activities.

\section{MATERIALS AND METHOD}

\section{Plant material}

The flowers and fruit peels of Musa sapientum were collected from local areas of Berhampur, Odisha, India, in the month of august 2017 and were identified by Dr. S. K. Dash, former professor, Department of Biosciences, College of Pharmaceutical Sciences, Mohuda, DistGanjam, Odisha. The plant materials were cleaned with deionized water and were air-dried under shade, coarsely powdered, and kept in airtight container.

\section{Animals}

Wistar albino rats weighing 150-200 $\mathrm{g}$ of either sex were used for this study. They were brought from animal house of Royal College of Pharmacy and Health Sciences (RCPHS), Berhampur, Odisha. Animals were maintained under controlled room temperature $\left(24 \pm 2^{\circ} \mathrm{C}\right)$ and a 12:12 hour light: dark cycle. The animals were fed with standard laboratory food diet made in-house recommended by National institute of nutrition, Hyderabad and pure drinking water ad libitum. The animals were acclimatized to laboratory hygienic conditions in the departmental laboratory for 7 days before commencing the experiment. The ethical clearance was granted for the study by Institutional animal ethics committee of RCPHS, Berhampur, Odisha (bearing registration number 1018/C/06/CPSEA and date of registration 19th Dec 2006) prior to the beginning of the experimental works.

\section{Preparation of extract}

Methanol extract of Musa sapientum flowers (MEMF) and Methanol extract of Musa sapientum fruit peels (MEMFP) were prepared by soxhlet apparatus by successive extraction with petroleum ether $\left(60-80^{\circ} \mathrm{C}\right)$, chloroform and methanol. Petroleum ether and chloroform were used in initial steps of extraction for defatting the plant materials. The methanol extracts were collected and dried using rotary vacuum evaporator followed by lyophilization and stored in

desiccator until further use ${ }^{\mathbf{1 8}, 19}$. The type and extractive yield of different extracts of Musa sapientum were observed and results of such observation are tabulated in table no 1. 
Table 1 Types and percentage yield of MEMF and MEMFP

\begin{tabular}{lllll}
\hline Sl. no. & Extracts & $\begin{array}{l}\text { Colour of the } \\
\text { extracts }\end{array}$ & $\begin{array}{l}\text { Physical } \\
\text { appearance of the } \\
\text { extracts }\end{array}$ & $\begin{array}{l}\text { \%Yield } \\
(\mathbf{w} / \mathbf{w})\end{array}$ \\
\hline 1 & MEMF & Light brown & $\begin{array}{l}\text { Dried powder } \\
\text { Dried powder }\end{array}$ & 17.08 \\
2 & MEMFP & Brown & Drien \\
\hline
\end{tabular}

\section{Phytochemical screening}

Qualitative analysis of MEMF and MEMFP were carried out for presence of various phytoconstituents based on standard protocols ${ }^{\mathbf{2 0 - 2 3}}$ and results of such observation are tabulated in table no 2.

Table 2 Preliminary phytochemical investigation MEMF anf MEMFP

\begin{tabular}{lll}
\hline phytoconstituents & MEMF & MEMFP \\
\hline Alkaloids & + & + \\
Carbohydrates & + & + \\
Glycosides & + & + \\
Cardiac glycosides & - & - \\
Saponin glycosides & + & + \\
Proteins and Amino acids & + & + \\
Tannins and phenolic compounds & + & + \\
Triterpenoids & + & + \\
Flavonoids & + & + \\
Coumarins & + & - \\
Steroids & - & - \\
Fats and oils & - & - \\
\hline
\end{tabular}

\section{Antidiarrheal Study}

\section{Castor oil-induced diarrhea}

After acclimation in the departmental laboratory for 7 days, the castor oil induced diarrhoea test was performed in wistar albino rats. Thirty six number of rats were randomly divided into six groups of six rats each $(n=6)$ and administered different drugs as per the following schedule. Group 1 was received only distilled water $5 \mathrm{ml} / \mathrm{kg}$ and served as control group animals; group 2, treated with $3 \mathrm{mg} / \mathrm{kg}$ of loperamide and served as standard group; group 3 and group 4 animals were treated with 200 and $400 \mathrm{mg} / \mathrm{kg}$ of MEMF respectively; group 5 and group 6 were treated with 200 and $400 \mathrm{mg} / \mathrm{kg}$ of MEMFP respectively. The rats were fasted for $18 \mathrm{~h}$ (free access to water) and were housed separately in metabolic cages. The animals administered the above drugs to respective groups. Thirty minutes after drug treatment the animals were administered with 1 $\mathrm{ml}$ of castor oil orally. The numbers of both wet and dry diarrhoeal droppings were counted 
every hour for a period of 4 hours. At the end of 4th hour, the cumulative wet and dry weight of stool mass was weighed. Percent reduction in stool mass was calculated ${ }^{\mathbf{2 4 - 2 6}}$.

\section{Intestinal motility test}

Intestinal motility test was performed in wistar albino rats. Thirty six number of rats were randomly divided into six groups of six rats each $(n=6)$ and administered different drugs as per the following schedule. Group 1 was received only distilled water $5 \mathrm{ml} / \mathrm{kg}$ and served as control group animals; group 2, treated with $5 \mathrm{mg} / \mathrm{kg}$ of atropine sulfate and served as standard group; group 3 and group 4 animals were treated with 200 and $400 \mathrm{mg} / \mathrm{kg}$ of MEMF respectively; group 5 and group 6 were treated with 200 and $400 \mathrm{mg} / \mathrm{kg}$ of MEMFP respectively. The rats were fasted for $18 \mathrm{~h}$ (free access to water) and administered the above drugs to respective groups. Thirty minutes after drug treatment, $2 \mathrm{ml}$ of charcoal meal (consisting of activated charcoal $12 \mathrm{~g}$, tragacanth $2 \mathrm{~g}$, water $130 \mathrm{ml}$ ) was administered orally to all the rats ${ }^{\mathbf{2 6}}$. Thirty minutes later, the rats were sacrificed and the abdomen was opened. The small intestine was dissected out from the pyloric sphincter to the iliocecal junction and the distance covered by the charcoal meal in the small intestine was measured. Calculate the percentage of the distance traveled and statistically compare between the different groups ${ }^{\mathbf{2 6 - 2 8}}$.

\section{Statistical Analysis}

The values are expressed as mean \pm Standard Error Mean (SEM). The results were analyzed for statistical significance using one-way ANOVA (and nonparametric), followed by Bonferroni's Multiple Comparison Test (Graph pad prism 5.04 version). $P<0.05$ was considered statistically significant.

\section{RESULTS AND DISCUSSION}

\section{Phytochemical screening of the extracts}

The percentage yield (w/w) of MEMF was $17.08 \%$ and MEMFP was $15.64 \%$ (table 1). Preliminary phytochemical analysis of MEMF and MEMFP revealed the presence of alkaloids, carbohydrates, glycosides, saponins, proteins, coumarins, flavonoids, triterpenoids, tannins and phenolic compounds (table 2).

Notably the tannins, flavonoids and alkaloids have been reported to possess anti diarrhoeal activity. Tannins may precipitate proteins of enterocytes, reduce peristaltic movement and intestinal secretion. Flavonoids possesses anti diarrhoeal activity as it inhibits intestinal motility and hydroelectrolytic secretions. Flavonoids also have antioxidant properties for which it inhibits several enzymes including those involved in the arachidonic acid metabolism ${ }^{\text {29-31. }}$. 


\section{Antidiarrhoeal Study}

\section{Castor oil-induced diarrhea}

As expected, 30 min after administered the castor oil, diarrhea was found in all the animals of the control group. The treatment of loperamide had significantly $(\mathrm{P}<0.05)$ decreased the total number of diarrhoeal faeces and cumulative fecal mass in the standard group of rats. Loperamide (3 $\mathrm{mg} / \mathrm{kg}$ ) treated animals had shown $73.94 \%$ inhibition of diarrhoeal faeces and $86.44 \%$ inhibition of total weight of faeces as compared to control group animals. Treatment with both the extracts of MEMF and MEMFP of 200 and $400 \mathrm{mg} / \mathrm{kg}$ showed significant antidiarrhoeal effects in castor oil induced rats. Treatment with MEMF of 200 and $400 \mathrm{mg} / \mathrm{kg}$ caused 44.17\% and $62.78 \%$ inhibition of diarrhoeal faeces; $45.79 \%$ and $73.36 \%$ inhibition of total weight of faeces respectively. The MEMFP of 200 and $400 \mathrm{mg} / \mathrm{kg}$ caused inhibition of diarrhoeal faeces $39.49 \%$ and $58.46 \%$; inhibition of total weight of faeces $40.18 \%$ and $61.21 \%$ respectively (Table 3).

Table 3 Effect of MEMF and MEMFP in castor oil induced diarrhoea

\begin{tabular}{|c|c|c|c|c|c|}
\hline Groups & $\begin{array}{l}\text { Treated Drugs } \\
\text { and Doses }\end{array}$ & $\begin{array}{l}\text { Total } \\
\text { number of } \\
\text { Diarrhoeal } \\
\text { faeces }\end{array}$ & $\begin{array}{l}\text { \% inhibition } \\
\text { of Diarrhoeal } \\
\text { faeces }\end{array}$ & $\begin{array}{l}\text { Cumulative } \\
\text { fecal mass } \\
\text { (gm) }\end{array}$ & $\begin{array}{l}\% \text { inhibition } \\
\text { total weight } \\
\text { of faeces }\end{array}$ \\
\hline $\begin{array}{l}\text { Group } 1 \\
\text { Control }\end{array}$ & $\begin{array}{l}\text { Distilled water- } \\
0.5 \mathrm{ml} / 100 \mathrm{~g}\end{array}$ & $8.33 \pm 1.15$ & - & $2.14 \pm 0.39$ & - \\
\hline $\begin{array}{l}\text { Group } 2 \\
\text { Standard }\end{array}$ & $\begin{array}{l}\text { Loperamide- } 3 \\
\mathrm{mg} / \mathrm{kg}\end{array}$ & $2.17 \pm 0.90 *$ & 73.94 & $0.29 \pm 0.15^{*}$ & 86.44 \\
\hline $\begin{array}{l}\text { Group } 3 \\
\text { Test-I }\end{array}$ & $\begin{array}{l}\text { MEMF- } 200 \\
\mathrm{mg} / \mathrm{kg}\end{array}$ & $4.65 \pm 2.05^{*}$ & 44.17 & $1.16 \pm 0.67^{*}$ & 45.79 \\
\hline $\begin{array}{l}\text { Group } 4 \\
\text { Test-II }\end{array}$ & $\begin{array}{l}\text { MEMF- } 400 \\
\mathrm{mg} / \mathrm{kg}\end{array}$ & $3.1 \pm 1.62 * \#$ & 62.78 & $0.57 \pm 0.53$ *\# & 73.36 \\
\hline $\begin{array}{l}\text { Group } 5 \\
\text { Test-III }\end{array}$ & $\begin{array}{l}\text { MEMFP- } 200 \\
\mathrm{mg} / \mathrm{kg}\end{array}$ & $5.04 \pm 2.12 *$ & 39.49 & $1.28 \pm 0.44 *$ & 40.18 \\
\hline $\begin{array}{l}\text { Group } 6 \\
\text { Test-IV }\end{array}$ & $\begin{array}{l}\text { MEMFP- } 400 \\
\mathrm{mg} / \mathrm{kg}\end{array}$ & $3.46 \pm 1.43^{* \#}$ & 58.46 & $0.83 \pm 0.58 * \#$ & 61.21 \\
\hline \multicolumn{6}{|c|}{$\begin{array}{l}\text { The results were expressed as mean } \pm S E M, n=6 . \\
* P<0.05 ; \text { compared standard and test groups } v \text { s control group. } \\
\text { '\#' indicates there is no significant difference between standard and test drug at } P<0.05 \\
\text { ignificant level. }\end{array}$} \\
\hline
\end{tabular}




\section{Intestinal motility test}

In intestinal motility test all the rats of different groups were sacrificed, thirty minutes after administering $2 \mathrm{ml}$ of charcoal meal and distance covered by the charcoal meal in the small intestine was measured. In the control group animals $75.7 \%$ transit of charcoal meal was found. Atropine pretreated group produced a marked decrease in the propulsive movement and the intestinal length travelled by charcoal meal was $40.32 \%$. The percentage transit of charcoal meal in the animals pretreated with MEMF 200 and $400 \mathrm{mg} / \mathrm{kg}$ were $58.93 \%$ and $47.52 \%$ respectively. The percentage transit of charcoal meal in the animals pretreated with MEMFP 200 and 400 $\mathrm{mg} / \mathrm{kg}$ were $61.34 \%$ and $51.64 \%$ respectively (Table 4). The MEMF and MEMFP treated animals had significantly $(\mathrm{P}<0.05)$ decreased the intestinal transit of charcoal meal. The antimotility effects of $400 \mathrm{mg} / \mathrm{kg}$ of both the extract were comparable with standard drug atropine. The MEMF showed more anti-motility effect than the MEMFP in intestinal motility test.

Table 4 Effect of MEMF and MEMFP in intestinal motility test

\begin{tabular}{llll}
\hline Groups & Treated Drugs and Doses & \% Transit of charcoal meal & \% Inhibition \\
\hline Group 1 Control & Distilled water- 0.5 ml/ 100 g & $75.7 \pm 6.41$ & - \\
Group 2Standard & Atropine- 3 mg/kg & $40.32 \pm 4.78^{*}$ & 46.73 \\
Group 3Test-I & MEMF- 200 mg/kg & $58.93 \pm 7.08^{*}$ & 22.15 \\
Group 4Test-II & MEMF- 400 mg/kg & $47.52 \pm 4.16^{* \#}$ & 37.22 \\
Group 5Test-III & MEMFP- 200 mg/kg & $61.34 \pm 5.18^{*}$ & 18.96 \\
Group 6Test-IV & MEMFP- 400 mg/kg & $51.64 \pm 4.25^{*} \#$ & 31.78 \\
\hline
\end{tabular}

The results were expressed as mean $\pm S E M, n=6$.

$* P<0.05$; compared standard and test groups vs control group.

'\#' indicates there is no significant difference between standard and test drug at $P<0.05$ significant level.

\section{CONCLUSION}

The results of the present work provide evidence that methanol extract of Musa sapientum flowers and fruit peels have antidiarrhoeal and antimotility activity in a dose dependent manner.

The phytochemical study showed that the extract contains tannins, flavonoids and alkaloids may be responsible for management of diarrhoea. This study also scientifically justifies the traditional claim of usefulness of this plant against diarrhoea. Further investigation is necessary for isolation, identification and characterization of different active compounds from the extract and for elucidating their mode of action, responsible for these properties on different biological systems.

\section{ACKNOWLEDGMENTS}

The authors thank Royal College of Pharmacy and Health Sciences, Berhampur, Odisha, India, 
for providing infrastructure and facilities in the course of this investigation.

\section{REFERENCES}

1. Rao NV, Prakash KC. Pharmacological investigation of Cardiospermum halicacabum (Linn) in different animal models of diarrhea. Indian J pharmacol 2006; 38: 346-349.

2. Synder JD, Merson MH. The magnitude of the global problem of acute diarrhoea disease: A review of active surveillance data. Bull WHO 1982; 60: 605-13.

3. Mukherjee J, Das R, Balasubramania K, Saha M, Pal BP. Anti-diarrhoeal evaluation of Nelumbo nucifera rhizome extract. Indian J pharmacol 1995; 22: 262-264.

4. Chitme HR, Chandra R. Studies on anti-diarrhoeal activity of Calotropis Gigantea r. br. in experimental animals. J pharm pharmaceut sci 2004; 7(1): 70-75.

5. Fontaine O. Diarrhea and treatment. Lancet 1998; 28:1234-1235.

6. Dey A, Panigrahi G, Deb L, Nongalleima K, Patra P. Evaluation of anti-diarrhoeal activity of ethanolic leaf extract of Scoparia dulcis linn on wister albino rats. Indian J Res in Phar and Biotech 2013; 1(1): 78-81.

7. Agarwal PK, Singh A, Gaurav K, Goel S, Khanna HD, Goel RK. Evaluation of wound healing activity of extracts of plantain banana (Musa sapientum var. paradisiaca) in rats. Indian J Exp Biol 2009; 47: 322-40.

8. Ehiowemwenguan G, Emoghene AO, Inetianbor JE. Antibacterial and phytochemical analysis of Banana fruit peel. IOSR J Pharm 2014; 4(8): 18-25.

9. Imam MZ, Akter S. Musa paradisiaca L. and Musa sapientum L. : A Phytochemical and Pharmacological Review. J Appl Pharmaceut Sci 2011; 01(05): 14-20.

10. Anhwange BA, Ugyeans TJ, Nyiaatagher TD. Chemical composition of Musa sapientum (Banana) peels. EJEAF Che 2009; 8: 437-442.

11. Bhat MS, Prabhakar A, Rama KRR, Madhu GM, Rao GH. Statistical optimization and neural modeling of amylase production from banana peel using Bacillus subtilis MTCC 441. International J of Food Eng 2010; 56: 34-45.

12. Amit R, Shailandra S. Ethnomedicinal approach in biological and chemical investigation of phytochemicals as antimicrobials. Indian J of Pharmaceut Sci 2006; 41: 1-13.

13. Ghani A. Medicinal Plants of Bangladesh: Chemical Constituents and Uses. 2nd ed., Dhaka, Bangladesh: The Asiatic Society of Bangladesh; 2003.

14. Khare CP. Indian Medicinal Plants. 1st ed., New York, USA: Springer Science + Business Media; 2007. 
15. Partha P, Hossain AB. Ethnobotanical Investigation into the Mandi Ethnic Community in Bangladesh. Bangladesh J of Plant Taxon 2007; 14(2): 129-145.

16. Okoli RI, Aigbe O, Ohaju-Obodo JO, Mensah JK. Medicinal herbs used for managing some common ailments among Esan People of Edo State, Nigeria. Pakistan J Nutr 2007; 6(5): 490-496.

17. Coe F, Anderson GJ. Ethnobotany of the Sumu (Ulwa) of southeastern Nicaragua and comparisons with Miskitu plant lore. Econ Bot 1999; 53: 363-383.

18. Panigrahi G, Panda C, Patra A. Extract of Sesbania grandiflora Ameliorates Hyperglycemia in High Fat Diet-Streptozotocin Induced Experimental Diabetes Mellitus. Scientifica 2016; 16: 1-10.

19. Panigrahi G, Mishra US, Mahapatra S, Panda C, Pasa G, Hati DK. Hypoglycemic and hypolipidemic activities of methanolic extract of Glinus oppositifolius. International J of Pharm 2012; 2(3): 491-497.

20. Kokate CK, Purohit AP, Gokhale SB. Text Book of Pharmacognosy. 20th ed., Pune, India: Nirali Prakashan; 2002.

21. Evans WC. Trease and Evans Pharmacognosy. 15th ed., Edinburgh, Scotland: W.B. Saunders; 2002.

22. Khandelwal KR. Practical Pharmacognosy. 14th ed., Pune, India: Nirali Prakashan; 2005.

23. Panda C, Mishra US, Mahapatra S, Panigrahi G. Free radical scavenging activity and phenolic content estimation of Glinus oppositifolius and Sesbania grandiflora. International J of Pharm 2013; 3(4): 722-727.

24. Jebunnessa USB, Mahabub UZM, Akter R, Ahmed NU. Antidiarrhoeal activity of ethanolic bark extract of Mitragyna diversifolia. Bangladesh J Pharmacol 2009; 4: 144146.

25. Awouters F, Nimegrees CJE, Lenaerts FM, Janssen PAJ. Delay of castor oil diarrhoea in rats: A new way to evaluate inhibitors of prostaglandin biosynthesis. J Pharmacol 1978; 30: 41-45.

26. Ghosh MN. Fundamentals of experimental pharmacology. $5^{\text {th }}$ ed., Kolkata: Hilton \& Company; 2011: 157.

27. Akuodor GC, Muazzam I, Usman IM, Megwas UA, Akpan JL, Chilaka KC, Okoroafor DO, Osunkwo UA. Evaluation of the antidiarrhoeal activity of methanol leaf extract of Bombax buonopozense in rats. Ibnosina J Med BS 2011; 3(1): 15-20. 
28. Bijender S, Harish D. Effect of vitamin E on the impaired gastrointestinal activity of streptozotocin induced diabetic rats. Indian J Parmacology 2003; 35: 186-197.

29. Yu LL, Liao JF, Chen CF. Antidiarrhoeal effect of water extracts of Evodiae fructus in mice. J Ethnopharmacol 2000; 73: 39-45.

30. Di Carlo G, Autore G, Izzo AA, Maibline P, Mascolo N, et al. Inhibition of intestinal motility and secretion by flavonoids in mice and rats: structure activity relationship. $\mathrm{J}$ Pharm Pharmacol 1993; 45: 1054-1059.

31. Su YL, Leung LK, Bi YR, Huang Y, Chen ZY. Antioxidant activity of flavonoids isolated from Scutellaria rehderiana. J Am Chem Soc 2000; 77: 807-812. 